\title{
Production of Activated Carbon and Characterization from Snail Shell Waste (Helix pomatia)
}

\author{
Rhoda Habor Gumus*, Ideyonbe Okpeku \\ Department of Chemical and Petroleum Engineering, Niger Delta University, Wilberforce Island, Nigeria \\ Email: rhodagumus@yahoo.com
}

Received 24 December 2014; accepted 7 January 2015; published 15 January 2015

Copyright (C) 2015 by authors and Scientific Research Publishing Inc.

This work is licensed under the Creative Commons Attribution International License (CC BY).

http://creativecommons.org/licenses/by/4.0/

(c) () Open Access

\begin{abstract}
Snail shell waste (Helix pomatia) has been evaluated as raw material for the preparation of activated carbon using $\mathrm{ZnCl}_{2}$ and $\mathrm{CaCl}_{2}$ with the temperature ranging from $500^{\circ} \mathrm{C}$ to $800^{\circ} \mathrm{C}$. The activated carbon prepared was characterized, showing effect of temperature on ash content, pore volume and porosity. The adsorption isotherm for methylene blue was carried out on the activated carbon in a batch study. The adsorbent exhibited excellent adsorption for methylene blue. The experimental data were used for both Langmuir and Freundlich models. The adsorption coefficients of Langmuir isotherm were found to be 0.996 and 0.957 for $\mathrm{CaCl}_{2}$ and $\mathrm{ZnCl}_{2}$ while 0.969 and 0.962 were obtained for the Freundlich isotherm respectively. The value of $R_{L}$ was found to be 0.75 and 0.38 for samples $\mathrm{CC}$ and $\mathrm{ZZ}$ respectively, which is an indication that activated carbon impregnated with $\mathrm{CaCl}_{2}$ and $\mathrm{ZnCl}_{2}$ is favourable for adsorption of methylene blue under the conditions used in this study.
\end{abstract}

\section{Keywords}

Activated Carbon, Snail Shell Waste, Methylene Blue, Adsorption

\section{Introduction}

In the last decade, public awareness over the quality of drinking water has attracted interest in the global world [1]. This is reflected in the demand for home water filter, designed to remove objectionable taste, odour and organic contaminants from water, which has experienced substantial growth.

"Corresponding author.

How to cite this paper: Gumus, R.H. and Okpeku, I. (2015) Production of Activated Carbon and Characterization from Snail Shell Waste (Helix pomatia). Advances in Chemical Engineering and Science, 5, 51-61. 
Activated carbon is widely used for the purpose due to the large surface area available for adsorption or chemical reactions [2] as a result of its high degree of micro porosity.

It has a high adsorption capability due to its high internal surface area and porosity formed during carbonization. The presence of activating agents and carbonization conditions influenced the development of pore structures [3]. These materials are characterized by their extraordinary large specific surface areas, well-developed porosity and tunable surface containing functional groups [4]. The surface oxygen functional groups can be easily introduced to the carbon by different activation methods including dry and wet oxidizing agents. Dry oxidation method involves the reaction with hot oxidizing gas such as steam and $\mathrm{CO}_{2}$ at temperatures above $700^{\circ} \mathrm{C}$ [5], while that of wet oxidation involves the reaction between the carbon surface and solutions of oxidizing agents such as phosphoric acid $\left(\mathrm{H}_{3} \mathrm{PO}_{4}\right)$, nitric acid $\left(\mathrm{HNO}_{3}\right)$, hydrogen peroxide $\mathrm{H}_{2} \mathrm{O}_{2}$, zinc chloride $\left(\mathrm{ZnCl}_{2}\right)$, potassium permanganate $\left(\mathrm{KMnO}_{4}\right)$, ammonia sulphate $\left(\mathrm{NH}_{4}\right)_{2} \mathrm{SO}_{8}$, potassium hydroxide $(\mathrm{KOH})$, etc. Its primary source is from organic material with high carbon content (coal, wood, peat, coconut shells, etc). Granular activated carbon is produced by grinding, adding a suitable binder to give it the hardness, re-compacting and crushing to the correct size.

It finds application in areas such as wastewater treatment, water purification, discoloration, and removal of toxic organics, heavy metals ions [6] and recovery of organic and inorganic compounds from gaseous and liquid streams. It is also used in the purification of electroplating solution (bright nickel plating solution) which is a main technique for the removal of organic impurities. Activated carbon is also utilized in both field and industrial processes such as spill cleanup, ground water remediation, gasoline dispersion operation, air purification, drinking water filtration and volatile organic compound capture from painting. Activated carbon is used to treat poisonings and overdoses following oral ingestion. It is thought to bind to poison and prevent its adsorption by the gastrointestinal tract. Activated carbon is $50 \% \mathrm{w} / \mathrm{w}$ combination with celite, chromatographic separation of carbohydrates (mono-, di-trisacchardes) using ethanol solution (5\% - 50\%) as mobile phase.

There has been an increasing interest in the production of activated carbon from agricultural by-products and industrial waste [7], such as cocoa pod husk [3], periwinkle shell [8], walnut shell, peach stone, physic nut waste, coconut shells, palm kernel shells, and bamboo stem wastes [9] [10]. Others include: olive stone, sugarcane bagasse, pecan shells, palm seed, apple pulp [11]-[14], rubber seeds, and molasses, resins, and dried sewage sludge paper mill sludge, old newspapers [15]-[19], and waste tires [20].

However, the preparation of activated carbon from snail shell waste is scarce in literature. The significant feature of snail shell-based activated carbon is that it is mostly made of calcium carbonate, crystals organized within a matrix of protein in two principal forms: aragonite and calcite. The crystal type in the shell of the land snail (Helix pomatia) is normally aragonite, but calcite has also been found in repaired areas of the shell. When calcium carbonate $\left(\mathrm{CaCO}_{3}\right)$ dissolves in any common acid, carbon dioxide $\left(\mathrm{CO}_{2}\right)$ is generated: the dissolution of $\mathrm{CaCO}_{3}$ in acetic acid $\left(\mathrm{CH}_{3} \mathrm{COOH}\right)$ can be represented as follows.

$$
\mathrm{CaCO}_{3}+2 \mathrm{CH}_{3} \mathrm{COOH} \rightarrow \mathrm{Ca}\left(\mathrm{CH}_{3} \mathrm{COO}\right)_{2}+\mathrm{H}_{2} \mathrm{O}+\mathrm{CO}_{2}
$$

Though the major composition of snail shell is calcium carbonate (97.5\%), it is composed of other elements like calcium phosphate, calcium silicate, magnesium carbonate, magnesium oxide, iron oxide, manganese oxide and other organic substances [21]. Snail shell is usually neglected and abundant agricultural waste. As a result of the chemical composition of the shell, it can be used in wastewater treatment either as a coagulant or as an adsorbent. Therefore it is interesting to develop snail shell activated carbon of high porosity. The objective of this work is to prepare study snail shell based activated carbon using $\mathrm{ZnCl}_{2}$ and $\mathrm{CaCl}_{2}$. The prepared activated carbon with characterized properties was used for removal of methylene blue for the adsorption isotherm.

\section{Experimental and Methods}

\subsection{Pre-Treatment of Waste Snail Shells}

The waste snail shells used in this study was supplied by local market traders (Amassoma). Prior to the carbonization and activation experiments snail shell were washed with warm water, rinsed with distilled water, dried at $105^{\circ} \mathrm{C}$ for 3 hours and then allowed to cool in desiccators.

\subsection{Carbonization/Activation}

The dried snail shells were carbonized in a Vecstar Furnace at different temperatures: $500^{\circ} \mathrm{C}, 600^{\circ} \mathrm{C}, 700^{\circ} \mathrm{C}$, and 
$800^{\circ} \mathrm{C}$ for 3 hours and the charred snail shells were allowed to cool to room temperature. The carbonized snail shells were chemically activated using two different methods.

\section{Method 1}

50 grams of the carbonized snail shell in $150 \mathrm{ml}$ of $0.5 \mathrm{M} \mathrm{ZnCl}_{2}$ solution was thoroughly mixed and heated until it formed slurry. The slurry was transferred to a crucible and heated at $800^{\circ} \mathrm{C}$ for 3 hours and allowed to cool to room temperature and washed with distilled water, dried in an oven at $110^{\circ} \mathrm{C}$ for 2 hours. The sample was cooled to room temperature and stored in an air-tight container, ready for use. The same procedure was repeated with 50 grams of the carbonized in $50 \mathrm{ml}$ of $25 \%$ concentrated solution of $\mathrm{CaCl}_{2}$, to soak the carbonized snail shells completely; for 3 minutes to allow absolute escape of gases formed from the exothermic reaction and covered with a lid for 24 hours. The sample was removed and transferred into a drain tray, for 30 minutes, washed repeatedly with distilled water to remove traces of chemical, drained and transferred into an oven at $110^{\circ} \mathrm{C}$ for 2 two hours, cooled and stored for use. The same was repeated at temperatures of $500^{\circ} \mathrm{C}, 600^{\circ} \mathrm{C}$, and $700^{\circ} \mathrm{C}$ for the both samples.

\subsection{Characterization}

\subsection{1. $\mathrm{pH}$}

2.0 grams of the adsorbent $\left(Z_{1}\right)$ was weighed out using a sensitive weighing balance. The weighed activated carbon was washed thoroughly for 5 minutes with $30 \mathrm{ml}$ distilled water and filtered using a filter paper and $\mathrm{pH}$ of filtrate was measured using a $\mathrm{pH}$ meter. This procedure was repeated for samples $Z_{2}, Z_{3}, Z_{4}$ and $C_{1}, C_{2}, C_{3}$, and $C_{4}$.

\subsubsection{Pore Volume and Porosity}

The same quantity sample $Z_{1}$ was transferred into a measuring cylinder of $(10 \mathrm{ml})$ and volume of the particles was recorded. This sample was placed into a beaker containing $20 \mathrm{ml}$ of distilled water and boiled for 5 minutes (to displace air in the sample). The content was superficially dried and weighed. The increase in weight of the sample divided by the density of water gave the pore volume for sample $Z_{1}$. Porosity was calculated by dividing the pore volume of the particle with the total volume of the particle.

\subsubsection{Ash Content}

2.0 grams of sample $Z_{1}$ was placed into a crucible, and reweighed with its content heated in a furnace at $900^{\circ} \mathrm{C}$ for 3 hours. The sample was cooled to room temperature and reweighed. Ash content was calculated between the differences in weight.

\subsubsection{Determination of Moisture Content}

2.0 grams of sample $Z_{1}$ was dried using a Moisture Analyzer at $150^{\circ} \mathrm{C}$, until weight of sample was constant. The moisture content was determined using the equation:

$$
X_{0}=\frac{W_{1}-W_{2}}{W_{1}} \times 100
$$

where $X_{0}=$ moisture content on wet basis, $W_{1}=$ initial weight of sample in grams, $W_{2}=$ final weight of sample (in grams) after drying.

\subsubsection{Bulk Density}

5.0 grams of sample $Z_{1}$ was transferred into $25 \mathrm{~cm}^{3}$ of distilled water using measuring cylinder. The volume of the water displaced was recorded. The bulk density was calculated by dividing the mass of the sample $Z_{1}$ by the volume of water displaced which was repeated for samples $Z_{2}, Z_{3}, Z_{4}, C_{1}, C_{2}, C_{3}$, and $C_{4}$.

\section{Adsorption Isotherm}

Varying weights ranging from 1 gram to 5 grams of the activated carbon carbonized activated at $800^{\circ} \mathrm{C}$ with $\mathrm{ZnCl}_{2}$ and $\mathrm{CaCl}_{2}$ were measured separately into $30 \mathrm{ml}$ of the prepared methylene blue solution and mixed thoroughly by a shaker machine for 5 minutes and left for 2 hours. The solution was filtered with a filter paper and 
the filtrate was collected for analysis. The equilibrium concentration was determined by using a spectrophotometer. The amount of adsorption at equilibrium, $q_{e}\left(\mathrm{mg} \cdot \mathrm{g}^{-1}\right)$, was calculated by

$$
q_{e}=\frac{\left(C_{o}-C_{e}\right) V}{W}
$$

where $C_{o}$ and $C_{e}\left(\mathrm{mg} \cdot l^{-1}\right)$, are the liquid-phase concentrations of methylene blue at initial and equilibrium, respectively. $V$ is the volume of the solution (liter), and $W$ is the mass of the dry adsorbent used (g).

\section{Results and Discussion}

Activated carbon was produced from waste snail shells by impregnating with $0.5 \mathrm{M} \mathrm{ZnCl}_{2}$ and $2.25 \mathrm{M} \mathrm{CaCl}_{2}$. The activated carbon was characterized to determine: $\mathrm{pH}$, moisture content, bulk density, pore volume, porosity, and ash content.

\subsection{Physical Properties}

Density is particularly important in sugar decolourization where high viscosity syrup is displaced through a column of activated carbon while bulk density is important when carbon is removed by filtration because it determines how many pounds can be contained in a filter of a given cake [22]. Samples $Z_{2}$ and $C_{2}$ gave the highest bulk density of $2.8 \mathrm{~g} / \mathrm{ml}$ and $2.0 \mathrm{~g} / \mathrm{ml}$ at $600^{\circ} \mathrm{C}$. Higher density provides greater volume activity and normally indicates better quality activated carbon [23].

When two carbons differing in bulk density are used at the same height per liter, the carbon having higher bulk density will be able to filter more liquor volume before the available cake space is filled. Carbon with an adequate density also helps to improve the filtration rate by forming an even cake. Generally, a carbon with a bulk density of about $0.5 \mathrm{~g} / \mathrm{ml}$ is adequate for sugar decolourization [24]. The $\mathrm{pH}$ of activated carbon may influence colour by changing the sensitive fraction of solution colourants, causing unreliable colour measurements [25]. Acid carbons for example may be a better decolourizer [26] [27], but a sugar refinery would seldom employ a highly acidic carbon because the acid would cause inversion of sucrose to non-crystallizable sugars with low yield [28]. The $\mathrm{pH}$ of sample $Z_{1}$ is 7.23, while sample $C_{3}$ has a $\mathrm{pH}$ of 7.36. The result showed that the Activated carbon impregnated with $\mathrm{ZnCl}_{2}$ and $\mathrm{CaCl}_{2}$ are alkaline. In sugar decolourization, a distinctively acidic activated carbon may cause inversion of sucrose, and if distinctively alkaline it can cause degradation of organic impurities [28]. Hence, a carbon pH of 6 - 8 is acceptable for most application [29]. Ash content of carbon is the residue that remains when the carbonaceous portion is burnt off. The ash consists of mainly minerals such as silica, aluminum, iron, magnesium and calcium.

Ash in activated carbon is not desirable and is considered an impurity. Ash leached into sugar liquor during the process of decolourization is known to cause uneven distribution of heat in the boiler during sugar crystallization. Ash may also infer with carbon adsorption and catalysis of adverse reactions. Ash in activated carbon is not desirable and is considered an impurity. Also, ash content may affect the $\mathrm{pH}$ of the carbon since the $\mathrm{pH}$ in most commercial carbon is produced by their inorganic components. Sample $Z_{4}\left(800^{\circ} \mathrm{C}\right)$ has relatively lower ash content compared to other samples. Figure 1 shows that increase in carbonization temperature reduces the ash content. It is known that materials with the lowest ash content are most active [30]. The trend is different with $\mathrm{ZnCl}_{2}$ where the ash content increases with temperature to a peak of 88 and sharply decreased to 25 .

The moisture content is the amount of water physically bound to the activated carbon under normal condition. The moisture content of activated carbon dopped with $\mathrm{ZnCl}_{2}$ and $\mathrm{CaCl}_{2}$ respectively; samples $Z_{4}$ and $C_{4}$ have moisture content of less than $1 \%$, while sample $Z_{3}$ and $C_{1}$ have the highest moisture of $1.75 \%$ and $1.70 \%$ respectively. Studies have shown that lower moisture content increases the rate of adsorption of contaminants [22]. The practical limit for the level of moisture content allowed in activated carbon varies within 3\% - 6\% [22]. The moisture content also have the same trend to that of ash content but $C_{4}$ has lower moisture content compared to $Z_{4}$ at $800^{\circ} \mathrm{C}$ (see Figure 2).

It has been established that the large internal area of activated carbon is attributed to its porosity [31]. Sample $Z_{4}$ and $C_{4}$ have the highest porosity value in their respective categories. This shows that increase in activation temperature increases the porosity, as indicated in samples $Z_{1}$ and $Z_{2}(0.35,0.50)$ and $C_{1}$ and $C_{2}(0.28,0.38)$ but 


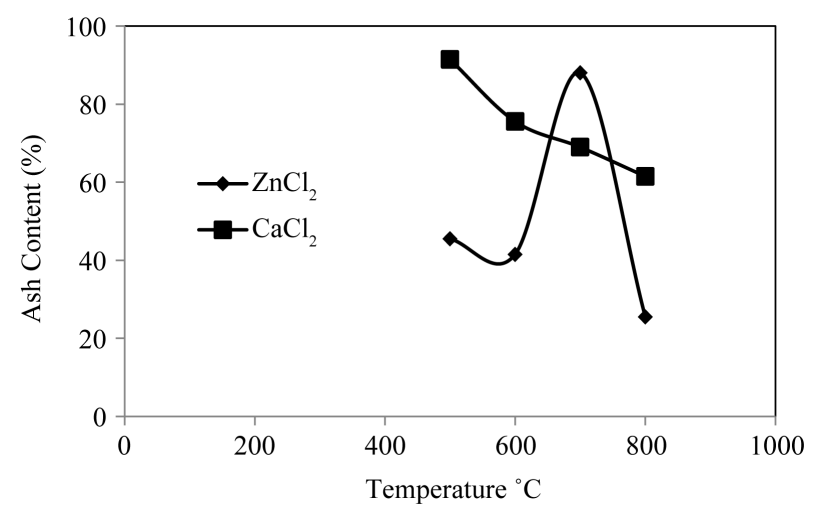

Figure 1. Effect of temperature on ash content dopped with $\mathrm{ZnCl}_{2}$ and $\mathrm{CaCl}_{2}$ activated carbon.

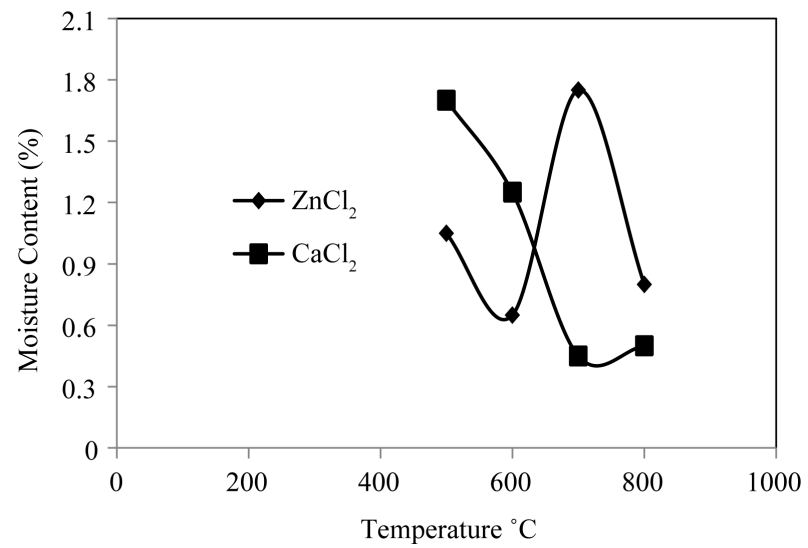

Figure 2. Effect of temperature on moisture content dopped with $\mathrm{ZnCl}_{2}$ and $\mathrm{CaCl}_{2}$.

samples $Z_{3}$ and $C_{3}$ seemed to deviate from that pattern as there was a little decrease in the porosity $(0.48,0.29)$. Figure 3 shows a steady rise in porosity from $500^{\circ} \mathrm{C}$ to $600^{\circ} \mathrm{C}$, and decreased in porosity at $700^{\circ} \mathrm{C}$, then showed an exponential rise to $800^{\circ} \mathrm{C}$. The porosity is as a result of the doping agents that helped degradation of organic material to release volatile matter and development of micro porous structure [32]. A similar trend was observed with pore volume impregnated with $\mathrm{ZnCl}_{2}$, where there was increase as temperature increases and showed a decrease at $700^{\circ} \mathrm{C}$. For the $C_{4}$ sample, the pore volume increased with an increase in temperature (Figure 4).

\subsection{Adsorption Isotherm}

Adsorption equilibrium is the most significant and helpful data in an adsorption system. It is also helpful in model prediction for analysis and design of an adsorption process. Methylene blue number is correlated with the ability of activated carbon to adsorb colour and high molecular weight substances. Several equilibrium isotherm equations namely, Langmuir, Freundlich, etc. have been evaluated to represent the experimental sorption isotherm data.

Figure 5 shows result of methylene blue adsorption onto snail shell activated carbon conducted in batch studies. The methylene blue adsorption followed the Langmuir isotherm which is consistent with results of others [33].

Langmuir Model

The linear form of Langmuir's isotherm model is given by the following equation.

$$
\frac{C_{e}}{q_{e}}=\frac{1}{K_{L}}+\frac{a_{L}}{K_{L}} C_{e}
$$




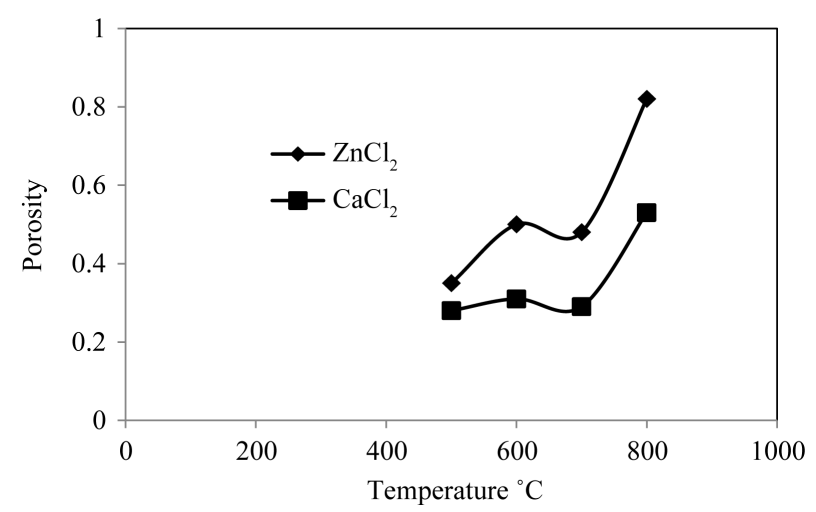

Figure 3. Effect of temperature on porosity dopped with $\mathrm{ZnCl}_{2}$ and $\mathrm{CaCl}_{2}$.

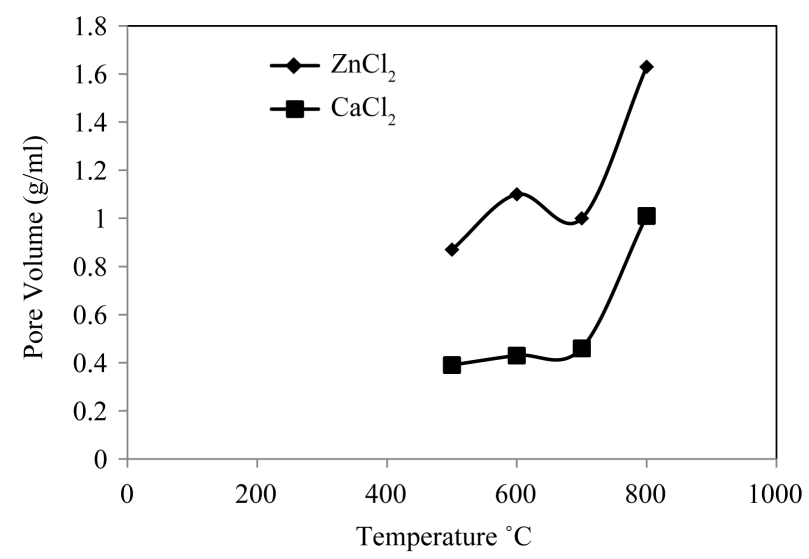

Figure 4. Effect of temperature on pore volume dopped with $\mathrm{ZnCl}_{2}$ and $\mathrm{CaCl}_{2}$.

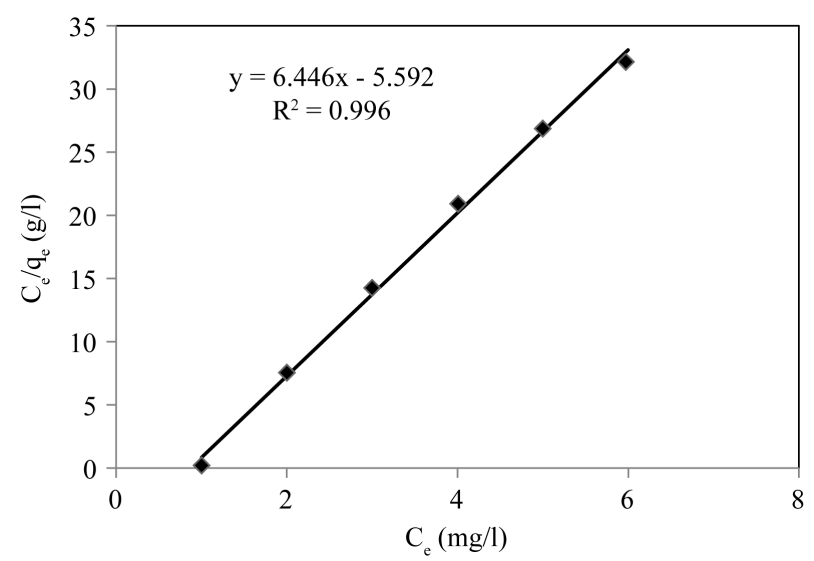

Figure 5. Adsorption isotherm of methylene blue dye on activated carbon dopped with calcium chloride.

where $C_{e}$ is the equilibrium concentration of the adsorbate (methylene blue) (mg/l), $q_{e}$ is the amount of adsorbate adsorbed per unit mass of adsorbate (mg/l), $\frac{1}{K_{L}}$ is the intercept which is related to monolayer adsorption of adsorbent towards adsorbate, $\frac{a_{L}}{K_{L}}$ is the slope obtained when $\frac{C_{e}}{q_{e}}$ was plotted against $C_{e}$ in Figure 5 and 
Figure 6 for samples CC and ZZ respectively, $k_{L}$ and $\frac{a_{L}}{K_{L}}$ were calculated from this isotherm (see Table 1). The essential characteristics of the Langmuir isotherm can be expressed in terms of a dimensionless equilibrium parameter $\left(R_{L}\right)$ [34] defined by

$$
R_{L}=\frac{1}{a_{L}}+K_{L}
$$

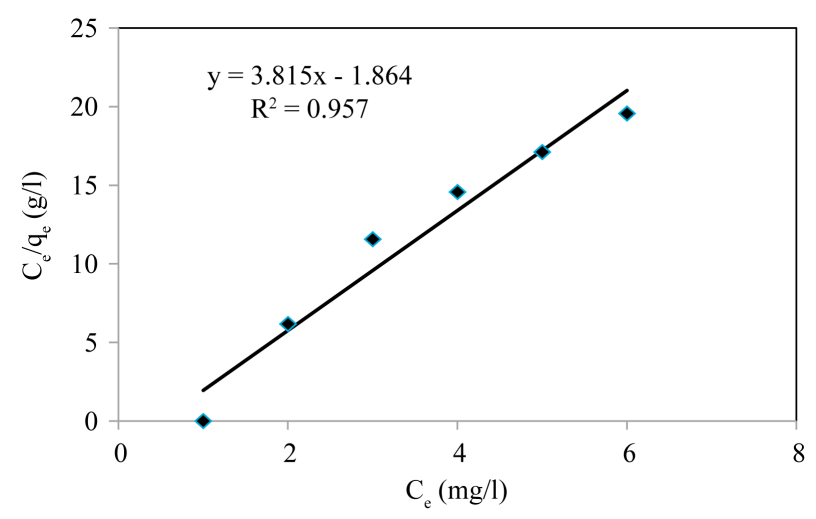

Figure 6. Adsorption isotherm of methylene blue dye on activated carbon dopped with $\mathrm{ZnCl}_{2}$.

Table 1. Samples and description.

\begin{tabular}{|c|c|}
\hline Sample & Description \\
\hline A1 & Carbonized at $500^{\circ} \mathrm{C}$ and activated using $0.5 \mathrm{M} \mathrm{ZnCl}_{2}$ \\
\hline A2 & Carbonized at $600^{\circ} \mathrm{C}$ and activated using $0.5 \mathrm{M} \mathrm{ZnCl}_{2}$ \\
\hline A3 & Carbonized at $700^{\circ} \mathrm{C}$ and activated using $0.5 \mathrm{M} \mathrm{ZnCl}_{2}$ \\
\hline A4 & Carbonized at $800^{\circ} \mathrm{C}$ and activated using $0.5 \mathrm{M} \mathrm{ZnCl}_{2}$. \\
\hline $\mathrm{C} 1$ & Carbonized at $500^{\circ} \mathrm{C}$ and activated using $\mathrm{CaCl}_{2}$ (25\%) \\
\hline $\mathrm{C} 2$ & Carbonized at $600^{\circ} \mathrm{C}$ and activated using $\mathrm{CaCl}_{2}(25 \%)$ \\
\hline C3 & Carbonized at $700^{\circ} \mathrm{C}$ and activated using $\mathrm{CaCl}_{2}$ (25\%) \\
\hline C4 & Carbonized at $800^{\circ} \mathrm{C}$ and activated using $\mathrm{CaCl}_{2}(25 \%)$ \\
\hline CC1 & 1 gram of $\mathrm{CaCl}_{2}$ activated carbon \\
\hline CC2 & 2 grams of $\mathrm{CaCl}_{2}$ activated carbon \\
\hline CC3 & 3 grams of $\mathrm{CaCl}_{2}$ activated carbon \\
\hline CC4 & 4 grams of $\mathrm{CaCl}_{2}$ activated carbon \\
\hline CC5 & 5 grams of $\mathrm{CaCl}_{2}$ activated carbon \\
\hline ZZ1 & 1 gram of $\mathrm{ZnCl}_{2}$ activated carbon \\
\hline ZZ2 & 2 grams of $\mathrm{ZnCl}_{2}$ activated carbon \\
\hline ZZ3 & 3 grams of $\mathrm{ZnCl}_{2}$ activated carbon \\
\hline ZZ4 & 4 grams of $\mathrm{ZnCl}_{2}$ activated carbon \\
\hline ZZ5 & 5 grams of $\mathrm{ZnCl}_{2}$ activated carbon \\
\hline
\end{tabular}


The value of $R_{L}$ indicates the type of isotherm to be either unfavourable $\left(R_{L}>1\right)$, linear $\left(R_{L}=1\right)$, favourable $\left(0<R_{L}<1\right)$, or irreversible $\left(R_{L}=0\right)$. The value of $R_{L}$ was found to be 0.75 and 0.38 for samples CC and ZZ respectively in Table 2 which is an indication that activated carbon impregnated with $\mathrm{ZnCl}_{2}$ is favourable for adsorption of methylene blue under the conditions used in this study.

\subsection{Freundlich Isotherm}

The well known logarithmic form of Freundlich model is given by the following equation

$$
\ln q_{e}=\ln K_{F}+\frac{1}{n} C_{e}
$$

where $q_{e}$ is the amount adsorbed at equilibrium ( $\left.\mathrm{mg} \cdot \mathrm{g}^{-1}\right), C_{e}$ is the equilibrium concentration of the adsorbate, $K_{F}$ is the adsorption capacity of the adsorbent $\left(\mathrm{mg} \cdot \mathrm{g}^{-1}\right)\left(\mathrm{mg}^{-1}\right)^{1 / n}, n$ indicates how favourable the adsorption process is, $\frac{1}{n}$ is the slope, ranging between 0 and 1 , a measure of adsorption intensity or surface heterogeneity, becoming more heterogeneous as its value gets closer to zero [34]. $\ln K_{F}$ is the intercept. Table 3 shows the result of $n$ and $K_{F}$, which can be defined as the adsorption or distribution coefficient and represents the quantity of methylene blue adsorbed in activated carbon adsorbent of a unit equilibrium concentration.

The plots of $\ln q_{e}$ versus $\ln C_{e}$ in Figure 7 and Figure 8 give straight lines with slope $1 / n$ of 0.364 and 0.320 for samples CC and ZZ respectively. This shows that the methylene blue adsorption conform to the model of Freundlich isotherm. The value of $1 / \mathrm{n}$ in both samples (CC and ZZ) indicates favourable adsorption [34].

With sample CC, the Langmuir model gives a better fit $\left(R^{2}=0.996\right)$ than the Freundlich model $\left(R^{2}=0.969\right)$, while ZZ for Freundlich model fits better $\left(R^{2}=0.962\right)$ than the Langmuir model $\left(R^{2}=0.957\right)$.

Table 2. Langmuir isotherm constants for methylene blue on activated carbon.

\begin{tabular}{ccccccc}
\hline Sample & $\frac{a_{L}}{K_{L}}$ & $\frac{1}{K_{L}}$ & $a_{L}$ & $K_{L}$ & $R_{L}$ & $R^{2}$ \\
\hline CC & 6.446 & 5.592 & 1.16 & 0.18 & 0.75 & 0.996 \\
ZZ & 0.3815 & 1.864 & 2.06 & 0.54 & 0.38 & 0.957 \\
\hline
\end{tabular}

Table 3. Freundlich isotherm constants for methylene blue.

\begin{tabular}{cccc}
\hline Sample & $n$ & $K_{F}\left(\mathrm{mg} \cdot \mathrm{g}^{-1}\right)\left(\mathrm{mg}^{-1}\right)^{1 / n}$ & $R^{2}$ \\
CC & 2.75 & 1.48 & 0.969 \\
$\mathrm{ZZ}$ & 3.13 & 1.48 & 0.962 \\
\hline
\end{tabular}

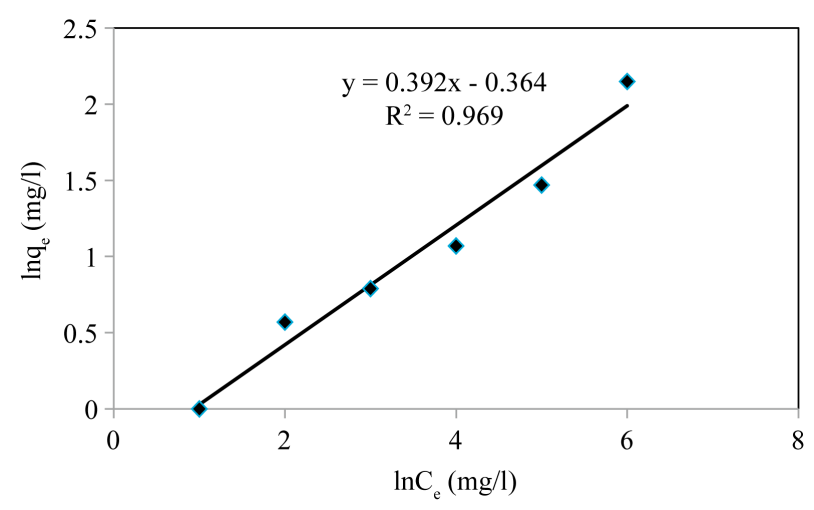

Figure 7. Adsorption isotherm of methylene blue dye on activated carbon impregnated with $\mathrm{CaCl}_{2}$. 


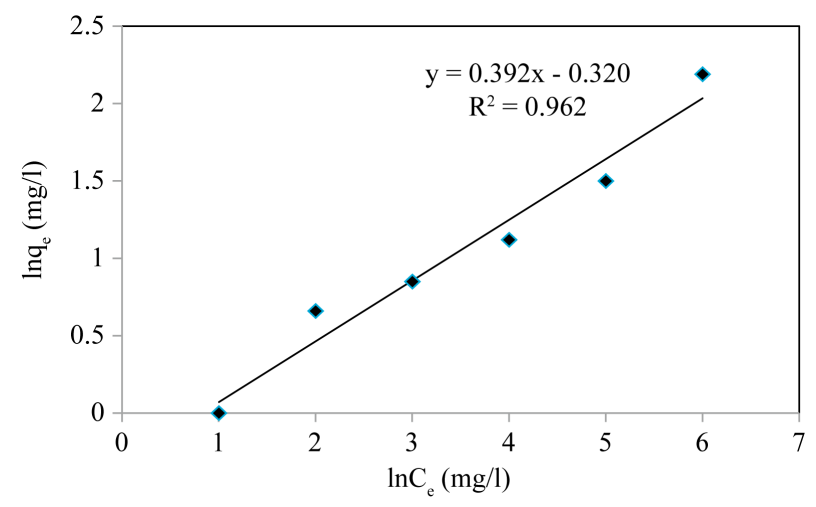

Figure 8. Adsorption isotherm of methylene blue dye on activated carbon impregnated with $\mathrm{ZnCl}_{2}$.

\section{Conclusion}

The porosity developed in the activated carbon is due to the impregnation of the doping agents $\left(\mathrm{ZnCl}_{2}\right.$ and $\mathrm{CaCl}_{2}$ ). This is because the chemical reactions caused by hydrolysis of the doping agents weaken the structure of the carbonized snail shell and release volatile matter which is responsible for the porosity and adsorption capacity of the carbon. Though, analysis indicated better porosity for activated carbon dopped with $\mathrm{ZnCl}_{2}$ compared to $\mathrm{CaCl}_{2}$. Both samples CC and ZZ showed favourable adsorption with better fit of $R^{2}=0.996,0.957$ and 0.969 , 0.962 for Langmuir and Freundlich respectively. Activated carbon from snail shell can be used to build filter systems for treatment of waste water from dye industry.

\section{Acknowledgements}

The Authors are grateful to the technologist in department of Chemistry, Niger Delta University, Wilberforce Island for analysis during this research work.

\section{References}

[1] Zang, F.S., Nriagu, J.O. and Ho, H. (2005) Mercury Removal from Waste Water Using Activated Carbons Derived from Organic Sewage Sludge. Water Research, 39, 389-395. http://dx.doi.org/10.1016/j.watres.2004.09.027

[2] Barret, E.P., Joyner, P.B. and Hatenda, P. (1951) The Determination of Pore Volume and Area Distribution in Porous Substances. Computations from Nitrogen Isotherms. Journal of Analytical Chemistry, 73, 373-380.

[3] Sricharoenchaikal, V., Pechyen, C., Ahl-ong, D. and Atong, D. (2007) Preparation and Characterization of Activated Carbon from the Pyrolysis of Physic Nut (Jatropha curcas L.) Waste Energy. Fuels, 22, 31-37. http://dx.doi.org/10.1021/ef700285u

[4] Rezaee, A., Godini, H. and Khavanin, A. (2008) Application of Impregnated Almond Shell Activated Carbon by Zine and Zine Sulfate for Nitrate Removal from Water. Iranian Journal of Environmental Health Science \& Engineering, 5, 125-130.

[5] Jabit, N.B. (2007) The Production and Characterization of Activated Carbon Using Local Agricultural Waste through Chemical Activation Process. http://eprints.usm.my/9576/1/THE_PRODUCTION_AND_CHARACTERIZATION_OF_ACTIVATED_CARBON_ USING_LOCAL_AGRICULTURAL_WASTE_THROUGH_CHEMICAL_ACTIVATION_PROCESS.pdf

[6] Rahmani, K., Mahvi, A.H., Vaezi, F., Mesdaghinia, A.R., Nabizade, R. and Nazmara, S. (2009) Bio Removal of Lead by Use of Waste Activated Sludge. International Journal of Environmental Research, 3, 471-476.

[7] Rahman, M.A., Asadultah, M., Haque, M.M., Motin, M.A., Sultan, M.B. and Azad, M.A.K. (2006) Preparation and Characterization of Activated Charcoal as an Adsorbent. Journal of Surface Science and Technology, 22, 133-140.

[8] Atuyor, E.O. and Badmus, M.A. (2008) COD Removal from Industrial Waste Water Using Activated Carbon Prepared from Animal Horns. African Journal of Biotechnology, 7, 3887-3891.

[9] El-Sheikh, A.H., Newman, A.P., Al-Daffa, H.K. and Crosswell, N. (2003) Characterization of Activated Carbon Prepared from a Single Cultivar of Jordanian Olive Stones by Chemical and Physico Chemical Techniques. Journal of Analytical Applied Pyrolysis, 30, 1-16. 
[10] Razada, R., Otoro, M., Moran, A. and Garcia, A.L. (2005) Activated Carbon from Sewage Sludge and Discarded Tyres: Production and Optimization. Journal of Harzadous Materials, 124, 181-191. http://dx.doi.org/10.1016/j.jhazmat.2005.05.002

[11] Kenneth, C.L., Nasrin, R.K., Marta, C., Giselle, S. and Thiyagarajan, P. (2002) Micro Structural Analysis of Activated Carbons Prepared from Paper Mill Sludge by SANS and BET. Chemical Materials, 14, 327-333. http://dx.doi.org/10.1021/cm010653u

[12] Girgis, B.S., Khalil, L.B. and Tawfik, T.A.M. (1994) Activated Carbon from Sugar Cane Bagasse by Carbonization in the Presence of Inorganic Acids. Journal of Chemical Technology and Biotechnology, 61, 87-92. http://dx.doi.org/10.1002/jctb.280610113

[13] Suzuti, M., Matsuzaka, A., Yamada, S., Shimono, M., Abiko, Y. and Lnoue, T. (2006) Morphology of Malassez’s Epithelial Rest-Like Cells in the Cementum: Transmission Electron Microscopy, Immunohistochemical, and TdT-Mediated dUTP-Biotin Nick End Labeling Studies. Journal of Periodontal Research, 41, 280-287. http://dx.doi.org/10.1111/j.1600-0765.2006.00871.x

[14] Ademituyi, F.T., Gumus, R.H., Adejini, S.M. and Jasem, O.T. (2009) Effect of Process Conditions on the Characterization of Activated Carbon from Waste Nigerian Bamboo. Journal of the Nigerian Society of Chemical Engineers, 24, 83-94.

[15] Ahmedna, M., Ctarke, S.J., Rao, R.M., Marshatt, W.E. and Johns, M.M. (1997) Use of Filtration and Buffers in Raw Sugar Colour Measurements. Journal of the Science of Food and Agriculture, 75, 109-116. http://dx.doi.org/10.1002/(SICI)1097-0010(199709)75:1<109::AID-JSFA849>3.0.CO;2-Y

[16] Baker, F.S., Mitter, C.E., Repic, A.J. and Tottes, E.D. (1992) Activated Carbon. Kirk-Othmer Encyctopedia of Chemicat Technotogy, 4, 1015-1037.

[17] Et-Hendway, A.A. (2003) Influence of $\mathrm{HNO}_{3}$ Oxidation on the Structured and Adsorptive Properties of Corncob Activated Carbon. Carbon, 41, 713-722.

[18] Smisek, M. and Cerney, S. (1970) Active Carbon: Manufacture, Properties and Applications. Elsevier, Amsterdam, 286-290.

[19] Puziy, A.M., Poddubnaya, O.T., Matinez-Atonso, A., Suaraz-Gareia, F. and Tascon, J.M.D. (2002) Characterization of Synthetic Carbon Activated with Phosphoric Acid. Applied Surface Science, 200, 196-202. http://dx.doi.org/10.1016/S0169-4332(02)00883-8

[20] Thomas, J.M. and Thomas, W.J. (1997) Principles and Practices of Heterogenous Catalysis. VCH Vertagsgeseldschaft MBH, Wanham, Federal Republic of Germany, 267-273.

[21] Srinivaskannan, C. and Abu Baker, M.Z. (2004) Production of Activated Carbon from Rubber Wood Sawdust. Biomass and Bio-Energy, 27, 89-96.

[22] Rengaraj, S., Moon, S.-H., Sivabalan, R., Arabindoo, B. and Murugesan, V. (2002) Agricultural Solid Waste for the Removal of Organics: Adsorption of Phenol from Water and Waste Water by Palm Seed Coat Activated Carbon. Waste Management, 22, 543-548. http://dx.doi.org/10.1016/S0956-053X(01)00016-2

[23] Laine, J., Catafat, A. and Labady, M. (1989) Preparation and Characterization of Activated Carbons from Coconut Shell Impregnated with Phosphoric Acid. Carbon, 27, 191-195. http://dx.doi.org/10.1016/0008-6223(89)90123-1

[24] Ahmedna, M., Johns, M.M., Ctarke, S.J., Marshall, W.E. and Rao, R.M. (1997) Potential of Agricultural By-ProductBased Activated Carbon for Use in Raw Sugar Decolourisation. Journal of the Science of Food and Agriculture, 75, 117-124. http://dx.doi.org/10.1002/(SICI)1097-0010(199709)75:1<117::AID-JSFA850>3.0.CO;2-M

[25] Lafi, W. (2001) Production of Activated Carbon from Acorns and Olive Seeds. Biomass and Bioenergy, 20, 57-62. http://dx.doi.org/10.1016/S0961-9534(00)00062-3

[26] El-Sheikh, A.H., Newman, A.P., Al-Daffaee, H.K., Phull, S. and Cresswell, N. (2003) Characterization of Activated Carbon Prepared from a Single Cultivar of Jordanian Olive Stones by Chemical and Physicochemical Techniques. Journal of Analytical and Applied Pyrolysis, 30, 1-16.

[27] Ahmedna, M., Marshall, W.E. and Rao, R.M. (2000) Production of Granular Activated Carbon from Select Agricultural By-Products and Evaluation of That Physical, Chemical and Adsorption Properties. Bioresource Technology, 71, 113-121. http://dx.doi.org/10.1016/S0960-8524(99)00070-X

[28] Menendez, J.A., Dominquez, A., Lguanzo, M. and Pis, J.J. (2005) Microwave Induced Drying, Pyrolysis and Gasification (MWDPG) of Sewage Sludge: Verification of the Solid Residue. Journal of Analytical and Applied Pyrolysis, 74, 406-412. http://dx.doi.org/10.1016/j.jaap.2004.10.013

[29] Akash, B.A. and O’Brien, W.S. (1996) The Production of Activated Carbon from Bituminous Coal. International Journal of Energy Resources, 20, 913-922. http://dx.doi.org/10.1002/(SICI)1099-114X(199610)20:10<913::AID-ER205>3.0.CO;2-7 
[30] Khalili, N.R, Campbell, M., Sandi, G. and Gola, J. (2000) Production of Micro and Mesoporous Activated Carbon from Paper Mill Sludge, Effect of Zinc Chloride Activation. Carbon, 38, 1905-1915. http://dx.doi.org/10.1016/S0008-6223(00)00043-9

[31] Rozada, F., Calvo, L.F., García, A.I., Martín-Villacorta, J. and Otero, M. (2003) Dye Adsorption by Sewage SludgeBased Activated Carbons in Batch and Fixed-Bed Systems. Bioresource Technology, 87, 221-230. http://dx.doi.org/10.1016/S0960-8524(02)00243-2

[32] Mui, E.L.K., Ko, D.C.K. and McKay, G. (2004) Production of Active Carbons from Waste Tyres. Carbon, 42, 27892805. http://dx.doi.org/10.1016/j.carbon.2004.06.023

[33] Yue, Z., Economy, J. and Bordson, G. (2006) Preparation and Characterization of NaOH-Activated Carbons from Phenolic Resin. Journal of Material Chemistry, 16, 1456-1461. http://dx.doi.org/10.1039/b513267c

[34] Lee, K.M. and Lim, P.E. (2003) Treatment of Phenolic Waste Water Using Agricultural Wastes Such as Adsorbent in a Sequencing Batch Reactor. Water Science Technology, 47, 41-47.

\section{Nomenclature}

$q_{e} \quad$ Amount adsorbe at equilibrium $\left(\mathrm{mg} \cdot \mathrm{g}^{-1}\right)$

$C_{e} \quad$ Equilibrium concentration of adsorbate (mg/l)

$K_{F} \quad$ Quantity of methylene blue adsorbed in activated carbon adsorbent of a unit equilibrium concentration $\left(\mathrm{mg} \cdot \mathrm{g}^{-1}\right)\left(\mathrm{mg}^{-1}\right)^{1 / n}$

$n \quad$ Adsorption or distribution coefficient 
Scientific Research Publishing (SCIRP) is one of the largest Open Access journal publishers. It is currently publishing more than 200 open access, online, peer-reviewed journals covering a wide range of academic disciplines. SCIRP serves the worldwide academic communities and contributes to the progress and application of science with its publication.

Other selected journals from SCIRP are listed as below. Submit your manuscript to us via either submit@scirp.org or Online Submission Portal.
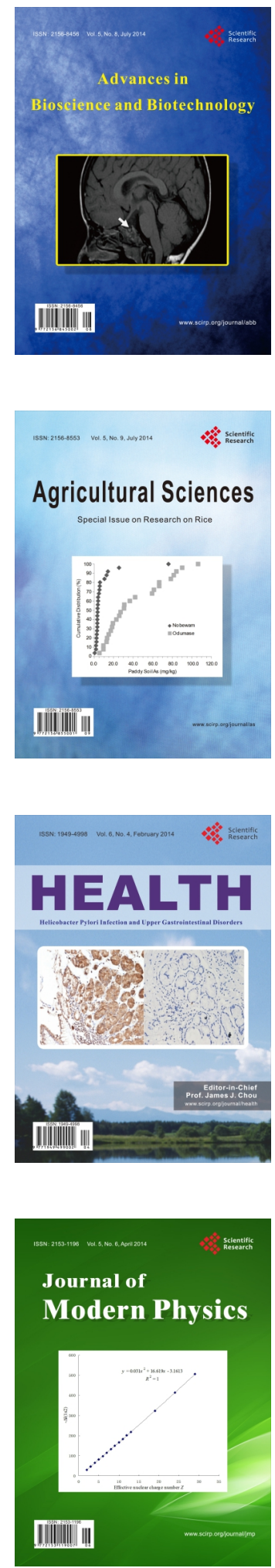
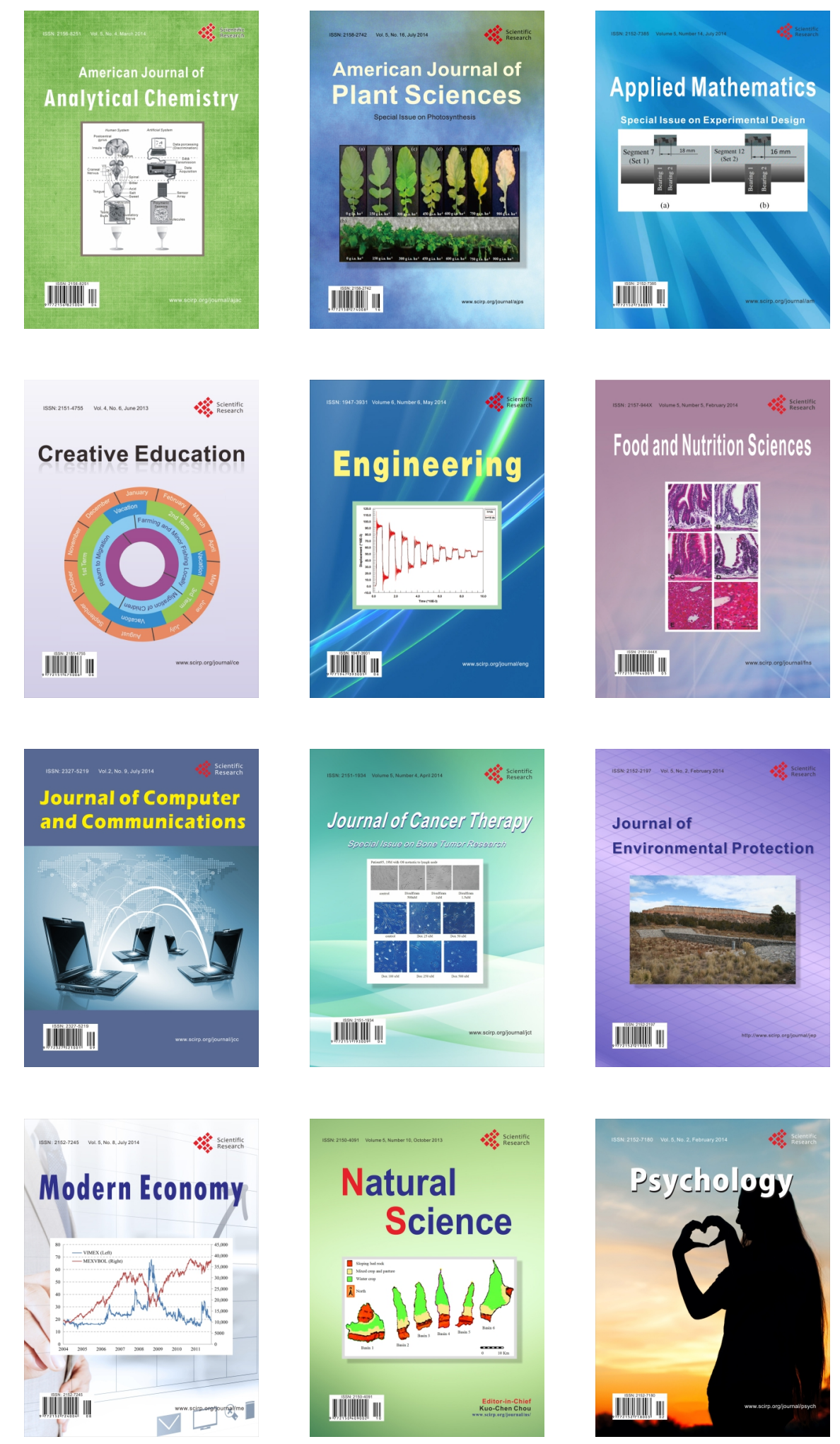